\title{
APLIKASI REGRESI DATA PANEL DALAM MENGANALISIS POTENSI DIVERSIFIKASI PASAR EKSPOR KAKAO OLAHAN INDONESIA KE NEGARA NON- TRADISIONAL TAHUN 2002-2018
}

(APPLICATION OF PANEL DATA REGRESSION IN ANALYSIS OF POTENTIAL DIVERSIFICATION OF INDONESIAN PROCESSED COCOA EXPORT MARKET TO NONTRADITIONAL COUNTRIES 2002-2018)

\author{
Prawesty Dian Utami ${ }^{1}$, Neli Agustina ${ }^{2}$ \\ 1,2Politeknik Statistika STIS
}

RT 09 RW 04 Desa Kranding Kelurahan Tamanan Trenggalek Jawa Timur

E-mail: 16.9355@stis.ac.id

\begin{abstract}
ABSTRAK
Sejak diberlakukan peraturan Menteri Keuangan No. 67/PMK.011/2010 tentang penetapan barang ekspor yang dikenakan Bea Keluar dan Tarif Bea Keluar, ekspor kakao dalam bentuk biji mengalami penurunan dan ekspor kakao olahan mulai meningkat. Namun, tingkat ketergantungan ekspor kakao olahan ke negara tradisional cukup tinggi. Terkonsentrasinya ekspor ke pasar tertentu dapat mengakibatkan kinerja ekspor rentan akan guncangan ekonomi yang terjadi pada pasar tersebut. Sehingga strategi yang dapat dilakukan Indonesia adalah melakukan diversifikasi pasar ekspor kakao olahan supaya kinerja ekspor lebih optimal. Penelitian ini bertujuan untuk mengidentifikasi negara non-tradisional yang berpotensi untuk pasar ekspor kakao olahan Indonesia dengan menggunakan analisis Export Product Dynamic (EPD) serta menganalisis variabel yang mempengaruhi ekspor kakao olahan ke negara non-tradisional tahun 2002-2018. Hasil penelitian menunjukkan bahwa negara Afrika Selatan, New Zealand, dan Turki memiliki potensi bagi diversifikasi pasar ekspor kakao olahan Indonesia. Hasil analisis regresi data panel menunjukkan PDB riil per kapita, harga ekspor kakao olahan, volume ekspor kakao olahan selain dari Indonesia, dan nilai tukar memiliki pengaruh positif signifikan terhadap volume ekspor kakao olahan.
\end{abstract}

Kata kunci: diversifikasi ekspor, kakao olahan, non-tradisional, EPD, regresi data panel

\begin{abstract}
Since minister of finance regulation No. 67/PMK.011/2011 about the determination of export goods subject to export duty and export duty tariffs has been applied, exports of cocoa bean decreased and exports of processed cocoa began to increase. However, the level of dependence on processed cocoa exports to traditional countries is quite high. Concentration of exports to certain markets can result in export performance vulnerable to economic shocks that occur in these markets. So, the strategy that can be done by Indonesia is market diversification on processed cocoa so that export performance is more optimal. The aim of this study is identifying non-traditional countries that have a potential market for Indonesian processed cocoa export using Export Product Dynamic (EPD) analysis and analyzing the variables that affect the export of processed cocoa to non-traditional countries in 2002-2018. The result showed that South Africa, New Zealand, and Turkey have the potential for the diversification of Indonesia's processed cocoa export market. Panel data regression analysis results showed real GDP per capita, the price of processed cocoa exports, the volume of processed cocoa exports other than Indonesia, and the exchange rate had a significant positive effect on the volume of processed cocoa exports.
\end{abstract}

Keywords: export diversification, processed cocoa, non-traditional, EPD, panel data regression 


\section{PENDAHULUAN}

Kakao merupakan salah satu komoditas andalan perkebunan yang peranannya cukup penting bagi perekonomian nasional, khususnya dalam memberikan sumbangan devisa ketiga terbesar setelah kelapa sawit dan karet (Goenadi et al., 2007). Rata-rata produksi biji kakao Indonesia selama tahun 2002-2018 sebesar 713 ribu ton. Kenaikan produksi biji kakao Indonesia menjadikan Indonesia sebagai negara penghasil kakao terbesar ke-3 dunia setelah Pantai Gading dan Ghana. Ekspor kakao Indonesia didominasi oleh ekspor dalam bentuk biji (bahan mentah), sehingga nilai tambah yang dihasilkan tidak sebanyak dibandingkan ekspor dalam bentuk olahan. Dalam rangka mendorong industri kakao, pemerintah mengeluarkan kebijakan dalam bentuk peraturan Menteri Keuangan No. 67/PMK.011/2010 tentang penetapan barang ekspor yang dikenakan Bea Keluar dan Tarif Bea Keluar. Pada tahun 2010 ekspor biji kakao Indonesia mencapai 432 ribu ton, setelah dikeluarkannya peraturan pemerintah ekspor biji kakao setiap tahunnya mengalami penurunan, tahun 2018 ekspor biji kakao Indonesia sebesar 27 ribu ton. Penurunan ekspor biji kakao Indonesia mendorong pemerintah untuk mengekspor kakao dalam bentuk yang bernilai tambah.

Selama periode 2002-2018 negara tujuan ekspor Indonesia didominasi oleh negara Jepang, Amerika Serikat, China, Singapura, dan India. Pasar tradisional merupakan negara tujuan utama ekspor Indonesia (Kemendag, 2013), yaitu negara yang secara insentif melakukan perdagangan international dengan Indonesia. Negara yang termasuk pasar tradisional Indonesia selain negara Jepang, Amerika Serikat, Cina, Singapura, dan India adalah Uni Eropa, Brazil, Filipina, dan Thailand. Pada tahun 2002-2018 pangsa ekspor pasar tradisional mencapai 84 persen dari total ekspor Indonesia. Terkonsentrasinya ekspor ke pasar tertentu dapat mengakibatkan kinerja ekspor rentan akan guncangan ekonomi yang terjadi pada pasar tersebut. Akibatnya terjadi penurunan ekspor kakao olahan sebagai akibat terjadinya krisis ekonomi di Amerika Serikat pada tahun 2008. Pada Gambar 1, ekspor kakao olahan Indonesia ke pasar tradisional mencapai 100 ribu ton pada tahun 2008 dan pada tahun 2009 mengalami penurunan sebesar 60 ribu ton.
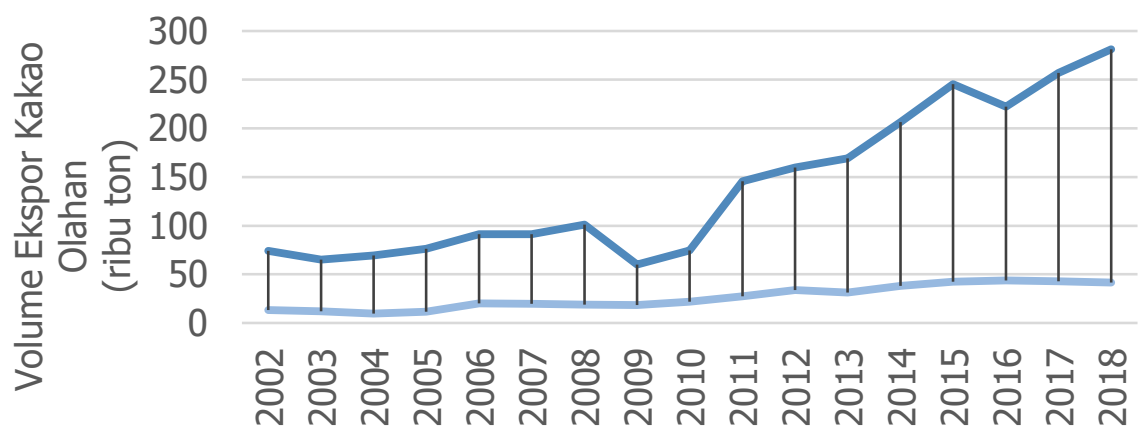

Tradisional

Non Tradisional

Tahun

\section{Sumber: UN Comtrade (diolah)}

Gambar 1. Volume ekspor kakao olahan Indonesia tahun 2002-2018 ke negara tradisional dan nontradisional (dalam ribu ton).

Ketidakstabilan pasar tradisional akan membawa dampak pada ketidakstabilan perekonomian Indonesia. Sehingga diperlukan strategi baru, salah satu cara yang dapat dilakukan adalah diversifikasi pasar ekspor kakao olahan ke negara yang potensial selain negara tujuan utama ekspor. Diversifikasi ekspor dipandang positif dalam mempertahankan pertumbuhan ekonomi suatu negara (Brenton, Newfarmer dan Walkenhorst 2007 dalam Siope, et al., 2012). Amurgo, Pacheco dan Pierola (2007) dalam pengamatannya berpendapat bahwa pada negara berkembang, diversifikasi geografis lebih penting dibandingkan dengan diversifikasi produk. Sehingga, untuk mengembangkan ekspor Indonesia, fokus dalam diversifikasi adalah diversifikasi pasar ekspor.

Berdasarkan uraian diatas, penulis tertarik untuk meneliti potensi diversifikasi ekspor kakao olahan serta mengkaji faktor-faktor yang berpengaruh terhadap ekspor kakao olahan Indonesia ke negara non-tradisional. Tujuan dari penelitian ini adalah: (1) menganalisis gambaran umum ekspor kakao olahan Indonesia ke negara non-tradisional tahun 2002-2018. (2) menganalisis potensi diversifikasi ekspor kakao olahan ke negara non-tradisional tahun 2002-2018. (3) mengkaji 
variabel-variabel yang mempengaruhi ekspor kakao olahan ke negara non-tradisional tahun 20022018.

Penelitian yang dilakukan oleh Kristina (2002) menunjukkan bahwa harga ekspor tekstil berpengaruh negatif signifikan dan nilai tukar berpengaruh positif signifikan terhadap volume eskpor tekstil Indonesia ke Jepang. Maulana (2017) menggunakan regresi data panel untuk meneliti daya saing ekspor kakao olahan Indonesia ke sembilan negara tujuan. Hasil penelitian menunjukkan bahwa PDB riil per kapita, bea keluar biji kakao, dan jumlah penduduk berpengaruh positif signifikan sedangkan harga riil ekspor memiliki pengaruh signifikan negatif terhadap volume ekspor kakao olahan Indonesia. Dewi (2017) menganalisis mengenai potensi diversifiksi pasar ekspor ban karet Indonesia ke Emerging Market Countries. Hasil penelitian menunjukkan bahwa nilai tukar dan foreign direct investment berpengaruh signifikan negatif terhadap volume ekspor ban karet, sedangkan PDB riil per kapita dan inflasi berpengaruh positif terhadap volume ekspor ban karet Indonesia. Kementrian Perdagangan (2011) melakukan kajian mengenai diversifikasi ekspor menggunakan model gravity menunjukkan bahwa variabel volume ekspor, GDP, nilai tukar, dan ecodistance berpengaruh nyata terhadap nilai ekspor produk.

\section{METODE}

Data yang digunakan dalam penelitian berupa data sekunder dari negara non-tradisional yang bersumber dari United Nation Comodity Trade (UN Comtrade), World Bank, dan International Monetary Fund (IMF). Negara non-tradisional yang terpilih terdiri dari Afrika Selatan, Selandia Baru, Arab Saudi, Sri Lanka, Ukraina, Mesir dan Turki yang merupakan negara non-tradisional tujuan utama ekspor kakao olahan Indonesia. Variabel-variabel yang digunakan dalam penelitian ini adalah sebagai berikut.

1. Volume ekspor kakao olahan Indonesia merupakan kuantitas kakao olahan Indonesia yang diekspor ke negara tujuan ekspor.

2. PDB riil per kapita merupakan rata-rata pendapatan penduduk di negara non-tradisional dalam satu waktu kurun tertentu. Data PDB riil per kapita diperoleh dalam satuan dolar AS per penduduk lalu dikonversikan menjadi ribu dolar AS per penduduk.

3. Nilai tukar riil merupakan harga relatif dari suatu barang dari dua negara (Mankiw, 2013) yang diperoleh dari mengalikan nilai tukar nominal dengan rasio indeks harga konsumen negara nontradisonal indeks harga konsumen AS.

4. Harga ekspor kakao olahan merupakan perbandingan antara nilai ekspor dengan volume ekspor kakao olahan.

5. Volume ekspor selain dari Indonesia menunjukkan total volume ekspor barang/jasa yang didatangkan dari Indonesia ke suatu negara tujuan ekspor tertentu (Pinandhita, 2018).

Analisis yang digunakan dalam penelitian ini berupa analisis deskriptif dan analisis inferensia. Analisis deskriptif yang digunakan adalah analisis Export Product Dynamic (EPD) untuk melihat posisi kakao olahan Indonesia di negara non-tradisional. EPD merupakan suatu kombinasi dari market share dan dynamic product. Market share merupakan pertumbuhan pangsa pasar total suatu negara di pasar tujuan ekspor, sedangkan dynamic product merupakan pertumbuhan permintaan produk suatu negara untuk pasar tujuan tertentu. Secara matematis, market share (sumbu x) suatu produk dirumuskan sebagai berikut (Kemendag, 2011).

$$
\text { sumbu } \mathrm{x}=\frac{\sum_{\mathrm{t}=1}^{\mathrm{n}}\left(\frac{\mathrm{x}_{\mathrm{ij}}}{\mathrm{W}_{\mathrm{ij}}}\right)_{\mathrm{t}} \times 100 \%-\sum_{\mathrm{t}=1}^{\mathrm{n}}\left(\frac{\mathrm{x}_{\mathrm{ij}}}{\mathrm{w}_{\mathrm{j}}}\right)_{\mathrm{t}-1} \times 100 \%}{\mathrm{~T}} .
$$

Sedangkan daya tarik pasar (sumbu y) secara matematis dirumuskan sebagai berikut (Kemendag, 2011).

$$
\text { sumbu } y=\frac{\sum_{t=1}^{n}\left(\frac{x_{j}}{w_{j}}\right)_{t} \times 100 \%-\sum_{t=1}^{n}\left(\frac{x_{j}}{w_{j}}\right)_{t-1} \times 100 \%}{T} . .
$$

dimana:

$\mathrm{X}_{\mathrm{ij}}=$ nilai ekspor produk i negara asal ke negara tujuan $\mathrm{j}$ 
$\mathrm{W}_{\mathrm{ij}}=$ nilai ekspor produk $\mathrm{i}$ dunia ke negara tujuan $\mathrm{j}$

$\mathrm{X}_{\mathrm{j}}=$ nilai total ekspor negara ke negara tujuan $\mathrm{j}$

$\mathrm{W}_{\mathrm{j}}=$ nilai total ekspor dunia ke negara tujuan eskpor

$\mathrm{i} \quad=$ komoditas

$\mathrm{j} \quad=$ negara tujuan ekspor

$\mathrm{t} \quad=$ periode

$\mathrm{T}=$ jumlah periode

Analisis inferensia yang digunakan berupa analisis regresi data panel untuk mengetahui variabel bebas apa saja yang berpengaruh terhadap ekspor kakao olahan ke negara nontradisional dengan model sebagai berikut.

$$
\mathrm{VOL}_{\mathrm{it}}=\mathrm{a}+\beta_{1} \mathrm{GDPRIILP}_{\mathrm{it}}+\beta_{2} \text { PRICE }_{\mathrm{it}}+\beta_{3} \mathrm{KURS}_{\mathrm{it}}+\beta_{4} \text { VOLRW }_{\mathrm{it}}+\mathrm{u}_{\mathrm{it}}
$$

dimana:

VOL $_{\text {it }} \quad=$ volume ekspor kakao olahan dari Indonesia ke negara non-tradisional-i pada tahun-t (ribu ton)

GDPRIILP $_{\text {it }}=$ PDB riil per kapita negara non-tradisional - i pada tahun-t (ribu dolar AS/penduduk)

PRICE $_{i t}=$ harga ekspor kakao olahan dari Indonesia di negara non-tradisional-i pada tahun-t (ribu dolar AS/ton)

KURS $_{\text {it }} \quad=$ nilai tukar riil negara non-tradisional-i pada tahun-t (dolar AS/mata uang negara non-tradisional)

VOLRW $_{\text {it }} \quad=$ volume ekspor kakao olahan ke negara non-tradisional-i selain dari Indonesia pada tahun-t (ribu ton)

$\mathrm{u}_{\mathrm{it}} \quad=$ error term

$\beta_{k} \quad=$ koefisien variabel bebas ke-k

$\mathrm{k} \quad=$ variabel bebas $(\mathrm{k}=1,2, \ldots, 4)$

$\mathrm{t} \quad=$ periode penelitian $(2002,2003, \ldots, 2018)$

$=$ negara non-tradisional $(1,2, \ldots, 7)$

\section{HASIL DAN PEMBAHASAN}

\section{GAMBARAN UMUM EKSPOR KAKAO OLAHAN DARI INDONESIA KE NEGARA NON- TRADISIONAL}

Terkonsentrasinya ekspor ke pasar tertentu dapat mengakibatkan kinerja ekspor rentan akan guncangan ekonomi yang terjadi pada pasar tersebut. Apabila negara-negara tersebut mengalami guncangan ekonomi, hal tersebut tentu akan mempengaruhi stabilitas ekspor Indonesia. Akibatnya terjadi penurunan ekspor kakao olahan sebagai akibat terjadinya krisis ekonomi di Amerika Serikat pada tahun 2008. Ketidakstabilan pasar tradisional akan membawa dampak pada ketidakstabilan perekonomian Indonesia sehingga salah satu cara yang dapat dilakukan adalah diversifikasi pasar ekspor kakao olahan ke negara non-tradisional.

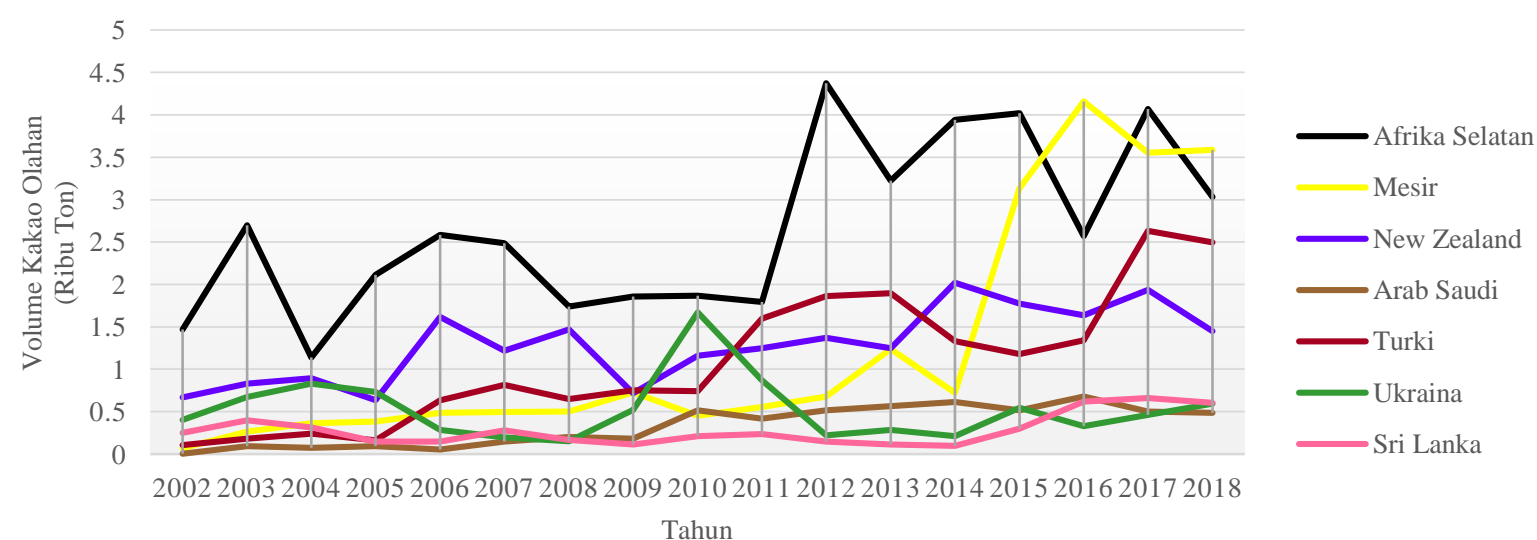




\section{Sumber: UN Comtrade (diolah)}

Gambar 2. Volume ekspor kakao olahan Indonesia tahun 2002-2018 ke negara non-tradisional (dalam ribu ton).

Pada Gambar 2. selama tahun 2002-2018 perkembangan ekspor kakao olahan ke tujuh negara non-tradisional menunjukkan kecenderungan yang berfluktuasi. Selama periode tersebut volume ekspor kakao olahan dari Indonesia ke negara non-tradisional mengalami peningkatan dengan rata-rata 13 persen tiap tahunnya. Ekspor kakao olahan ke Afrika Selatan paling tinggi dibandingkan negara non-tradisional lainnya yang menjadi tujuan eskpor Indonesia. Rata-rata ekspor ke negara tersebut mencapai 2,6 ribu ton tiap tahunnya. Sri Lanka merupakan negara tujuan ekspor Indonesia dengan volume ekspor paling rendah. Rata-rata ekspor kakao olahan Indonesia mencapai hanya 0,2 ribu ton per tahun.

Secara umum, jika dilihat dari Gambar 2, ekspor kakao olahan Indonesia ke tujuh negara mengalami peningkatan setelah tahun 2010. Dengan adanya kebijakan bea keluar ekspor biji kakao pada tahun 2010, ekspor kakao olahan ke negara non-tradisional meningkat sejak tahun tersebut. Meskipun masih terjadi penurunan pada satu dua negara pada rentang taun 2010 hingga 2018, namun rata-rata ekspor pada tahun tersebut meningkat

\section{POTENSI DIVERSIFIKASI EKSPOR KAKAO OLAHAN INDONESIA KE NEGARA NON- TRADISIONAL}

Kebijakan diversifikasi ekspor diperlukan untuk produk kakao olahan Indonesia karena pasar ekspornya masih terkonsentrasi ke negara tradisional, sedangkan untuk negara non-tradisional memiliki peluang namun pangsanya masih rendah. Pasar yang potensial untuk ekspor kakao olahan Indonesia dapat diidentifikasi melalui Export Product Dynamic (EPD).

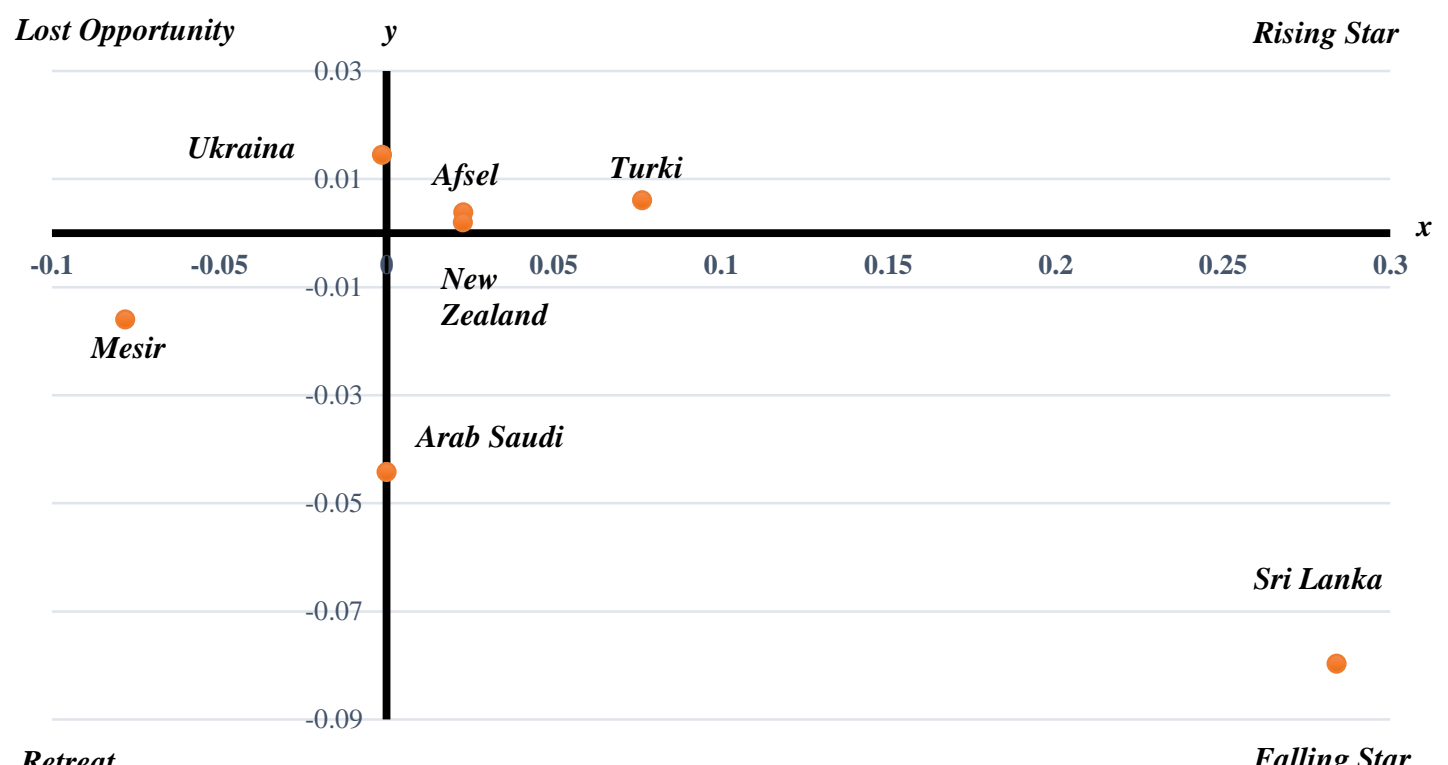

Gambar 3. Kuadran EPD kakao olahan dari Indonesia ke negara non-tradisional tahun 2002-2018.

Ekspor kakao olahan Indonesia di pasar non-tradisional di posisi rising star yaitu negara Afrika Selatan, New Zealand, dan Turki. Hal tersebut menunjukkan bahwa terdapat pertumbuhan pangsa pasar ekspor kakao olahan di pasar tersebut. Kenaikan pangsa pasar di tiga negara tersebut menunjukkan bahwa negara tersebut potensial untuk dijadikan pasar tujuan baru ekspor kakao olahan. Negara Ukraina berada dalam posisi lost opportunity, di mana hal tersebut mengindikasikan bahwa pertumbuhan pangsa pasar mengalami penurunan sehingga lebih rendah dibandingkan rata-rata pertumbuhan pangsa pasar dunia. Pada kondisi tersebut posisi daya saing kakao olahan tidak kompetitif namun masih memiliki keunggulan komperatif. Posisi falling star diduduki oleh negara Sri Lanka dan Arab Saudi. Pada posisi tersebut menunjukkan bahwa 
Indonesia belum dapat memaksimalkan kondisi pasar yang sedang mengalami peningkatan permintaan. Posisi retreat terjadi pada negara Mesir. Pada posisi tersebut, Indonesia tidak mempunyai potensi daya saing kakao olahan dan produk tersebut juga tidak diminati di negara Mesir. Tidak diminatinya produk kakao olahan Indonesia di negara Mesir karena terdapat beberapa hambatan dalam upaya meningkatkan ekspor kakao olahan ke kawasan tersebut. Salah satu hambatan tersebut adalah mahalnya biaya untuk melengkapi dokumen ekspor ke negara Mesir (Hasni, 2018).

\section{FAKTOR-FAKTOR YANG MEMPENGARUHI EKSPOR KAKAO OLAHAN KE NEGARA NON- TRADISIONAL TAHUN 2002-2018}

Analisis regresi data panel digunakan untuk mengetahui pengaruh dari variabel bebas yang terdiri dari PDB riil per kapita, harga ekspor kakao olahan, nilai tukar riil, dan volume ekspor kakao olahan selain dari Indonesia terhadap variabel terikat yaitu volume ekspor kakao olahan Indonesia ke negara non-tradisional tahun 2002-2018. Pemilihan model terbaik dalam regresi data panel, dimulai dengan uji Chow untuk menentukan model terbaik antara fixed effect atau common effect lalu dilanjutkan dengan uji signifikansi Hausman untuk menentukan model terbaik antara fixed effect atau random effect. Berdasarkan hasil kedua pengujian dengan taraf signifikansi lima persen, dapat disimpulkan bahwa model yang terbaik adalah fixed effect model.

Langkah selanjutnya yaitu melakukan pemeriksaan struktur varians covarians dengan menggunakan uji LM dan $\lambda_{\mathrm{LM}}$. Uji Lagrange multiplier digunakan untuk mengetahui struktur varians kovarians residual bersifat heterokedastisitas atau homoskedastisitas. Sedangkan, uji $\lambda_{\mathrm{LM}}$ digunakan untuk mengetahui ada tidaknya cross sectional correlation. Berdasarkan kedua uji tersebut, dengan tingkat signifikansi lima persen dapat disimpulkan bahwa struktur varian kovarians bersifat heterokedastisitas dan terdapat cross sectional correlation.

Langkah selanjutnya adalah pengujian asumsi klasik pada residual model terpilih. Asumsi klasik yang harus dipenuhi dalam model antara lain normalitas dan non-multikolinearitas. Dalam pengujian asumsi normalitas, pemeriksaan asumsi menggunakan uji Jarque-Berra sedangkan pemeriksaan non-multikolinearitas dengan melihat nilai VIF. Berdasarkan pengujian normalitas dengan menggunakan uji Jarque-Bera, residual pada model mengikuti distribusi normal. Sedangkan, pengujian non-multikolinearitas menggunakan nilai VIF menunjukkan bahwa nilai VIF dari masing-masing variabel bebas tidak ada yang melebihi 10 . Nilai tersebut mengindikasikan bahwa asumsi non-multikolinearitas telah terpenuhi.

Setelah dilakukan pengujian diatas, model yang terpilih yaitu fixed effect dengan penimbang yaitu SUR (Seemingly Unrelated Regression). Persamaan regresi yang dihasilkan adalah sebagai berikut.

$\widehat{V_{l t}}=-1,2840+\widehat{\mu}_{\mathrm{it}}+0,163225 \mathrm{GDPRIILP}_{\mathrm{it}}{ }^{*}+0,060457 \mathrm{PRICE}_{\mathrm{it}}{ }^{*}+0,002178$ KURS $_{i t}{ }^{*}+0,0021 \mathrm{VOLRW}_{\mathrm{it}}{ }^{*}(4)$

Adj. $R^{2}=0,8096$, Prob(F-stat) $=0,000$

*) signifikansi pada taraf lima persen

Berdasarkan nilai adjusted $R^{2}$, variabel PDB riil per kapita, harga ekspor kakao olahan, nilai tukar riil, dan volume ekspor kakao olahan selain dari Indonesia yang digunakan dalam model dapat menjelaskan 80,96 persen variasi dari volume ekspor kakao olahan Indonesia ke negara non-tradisional, sedangkan 19,04 persen dijelaskan oleh variabel lainnya yang tidak masuk ke dalam model.

Variabel PDB riil per kapita negara non-tradisional berpengaruh dan memiliki hubungan positif terhadap volume ekspor kakao olahan Indonesia. Hal tersebut ditunjukkan bahwa setiap kenaikan PDB riil per kapita sebesar seribu dolar AS per penduduk negara non-tradisional maka akan meningkatkan volume ekspor kakao olahan Indonesia ke negara non-tradisional sebesar 0,16 ribu ton, dengan variabel lain dianggap konstan. Hal ini sesuai dengan penelitian yang dilakukan oleh Suryana et al. (2014) yang menyatakan bahwa PDB riil per kapita negara tujuan berpengaruh positif terhadap volume ekspor kakao olahan Indonesia. Hubungan PDB riil perkapita negara tujuan ekspor dengan kinerja ekspor suatu negara yaitu dapat dilihat dari posisi PDB riil perkapita 
negara tersebut. Peningkatan PDB riil perkapita suatu negara akan meningkatkan daya beli masyarakat sehingga konsumsi barang dan jasa juga ikut meningkat.

Variabel harga ekspor kakao olahan Indonesia berpengaruh positif dan signifikan terhadap volume ekspor kakao olahan Indonesia di negara tujuan ekspor. Setiap kenaikan harga ekspor kakao olahan Indonesia sebesar seribu dolar AS di negara non-tradisional maka volume ekspor kakao olahan Indonesia di negara non-tradisional akan meningkat sebesar 0,06 ribu ton. Hal ini tidak sesuai dengan teori ekonomi dasar, bahwa harga suatu komoditas dengan kuantitas yang diminta berhubungan secara negatif, dengan faktor lain tetap sama (Lipsey, 1995). Meskipun harga produk Indonesia mengalami perubahan, konsumen akan tetap membelinya karena adanya efek ketergantungan terhadap produk tersebut. Raharjo (2013) dalam penelitiannya menyimpulkan suatu bahwa komoditas tidak elastis karena adanya efek ketergantungan terhadap barang tersebut sehingga tidak mudah untuk menggantikan dengan barang yang lain.

Selanjutnya, variabel nilai tukar riil negara non-tradisional menunjukkan hasil positif signifikan terhadap volume ekspor kakao olahan Indonesia. Setiap kenaikan nilai tukar negara non-tradisional maka volume ekspor kakao olahan Indonesia di negara non-tradisional akan meningkat sebesar 0,002 ribu ton. Salah satu penyebab hal tersebut adalah adanya kemungkinan tingginya impor pada kegiatan industri berorientasi ekspor, sehingga terjadi depresiasi nilai tukar di negara non-tradisional (Firdaus, 2017). Hal tersebut dapat menurunkan kemampuan produksi dalam negeri. Sehingga untuk menutupi kekurangan tersebut, negara non-tradisional lebih memilih membeli kakao olahan dari Indonesia terlebih harga kakao olahan Indonesia lebih murah.

Variabel terakhir adalah volume kakao olahan negara non-tradisional selain dari Indonesia. Berdasarkan hasil estimasi, variabel volume kakao olahan selain dari Indonesia berpengaruh positif signifikan terhadap ekspor kakao olahan Indonesia ke negara non-tradisional. Setiap kenaikan volume kakao olahan selain dari Indonesia sebanyak seribu ton maka volume ekspor kakao olahan Indonesia di negara non-tradisional akan meningkat sebesar 0,004 ribu ton. Hasil tersebut tidak sesuai dengan penelitian Pinandhita (2018), namun ketika ekspor kakao olahan selain dari Indonesia ke negara non-tradisional kurang mencukupi permintaan dari negara non-tradisional tersebut, maka kakao olahan Indonesia menyumbang untuk menutupi kekurangan permintaan kakao olahan di negara non-tradisional. Sehingga dapat disimpulkan bahwa ketika volume kakao olahan selain dari Indonesia meningkat maka volume ekspor kakao olahan dari negara Indonesia juga ikut meningkat.

Berdasarkan hasil estimasi (Tabel 1), terdapat hasil efek individu. Efek individu akan menyebabkan perbedaan pada nilai intersep ketika semua variabel bebas bernilai sama. Pada Tabel 1 menunjukkan bahwa Negara Afrika Selatan memiliki efek individu tertinggi yaitu sebesar 2,377319. Hal tersebut berarti ketika semua variabel bebas dianggap nol, maka rata-rata ekspor kakao olahan Indonesia ke negara Afrika Selatan sebesar 2,377.

Tabel 31. Output cross-section fixed effect.

No

(1)

1

2

3

4

5

6

7
Negara

(2)

Afrika Selatan

Mesir

New Zealand

Arab Saudi

Turki

Ukraina

Srilanka
Efek Individu

2,377319

1,754471

$-3,493516$

$-2,178712$

0,121839

0,769181

0,649417

\section{KESIMPULAN}

Berdasarkan uraian diatas, terdapat beberapa kesimpulan sebagai berikut. Pertama, selama tahun 2002-2018 hampir 84 persen ekspor kakao olahan Indonesia terkonsentrasi di pasar tradisional. Sejak tahun 2008, ekspor kakao olahan ke pasar tradisional mengalami penurunan mencapai 40 ribu ton pada tahun 2009. Dibandingkan dengan pasar tradisional, pasar non- 
tradisional ekspor kakao olahan Indonesia mengalami penurunan sebesar 412 ton. Secara keseluruhan, ekspor kakao olahan Indonesia ke pasar non-tradisional mengalami peningkatan setiap tahunnya. Berdasarkan uraian tersebut, Indonesia masih memiliki potensi untuk memperluas pasar ekspor ke negara non-tradisional.

Kedua, Berdasarkan hasil perhitungan EPD menunjukkan bahwa pasar non-tradisional yang potensial untuk diversifikasi adalah Afrika Selatan, New Zealand, dan Turki. Hal tersebut menunjukkan bahwa terdapat pertumbuhan pangsa pasar ekspor kakao olahan di negara tersebut. Kenaikan pangsa pasar di tiga negara tersebut menunjukkan bahwa negara tersebut potensial untuk dijadikan pasar tujuan baru ekspor kakao olahan. Sedangkan, negara yang kurang potensial adalah Mesir.

Ketiga, berdasarkan hasil analisis regresi data panel menunjukkan bahwa variabel PDB riil per kapita, harga, nilai tukar riil, dan volume ekspor selain dari Indonesia memiliki pengaruh positif signifikan terhadap volume ekspor kakao olahan ke negara non-tradisional.

\section{DAFTAR PUSTAKA}

Amurgo-Pacheco, Alberto dan Pierola, Martha Denisse. (2007). Patterns of Export Diversification in Developing Countries: Intensive and Extensive Margins. HEI Working Paper No. 20/2007. Geneva: Institute of International Studies.

Dewi. (2017). Potensi Diversifikasi Pasar Ekspor Ban Karet Indonesia ke Emerging Market Countries di Asia Afrika Tahun 2001-2015. Skripsi Sekolah Tinggi Ilmu Statistik. Jakarta. 106 hlm.

Goenadi, D.H., J.B. Baon, S. Abdullah, Herman dan A. Purwoto. (2007). Prospek dan Arah Pengembangan Agribisnis Kakao. Edisi Kedua. Badan Penelitian dan Pengembangan Pertanian, Departemen Pertanian, Jakarta.

Hasni, . (2018). DAYA SAING EKSPOR PRODUK MAKANAN OLAHAN INDONESIA KE TIMUR TENGAH. Buletin Ilmiah Litbang Perdagangan, 12(2), 235-266. Doi: https://doi.org/10.30908/bilp.v12i2.325

Kementrian Perdagangan. (2011). Kajian Kebijakan Pengembangan Diversifikasi Pasar dan Produk Ekspor. Jakarta: Kemendag.

Kementrian Perdagangan. (2013). Peluang dan Tantangan Ekspor ke Negara-Negara Non-Tradisional. Warta Ekspor Edisi Pebruari 2013. Diakses pada tanggal 14 September 2020 melalui http://djpen.kemendag.go.id/app frontend/admin/docs/publication/9421384233412.pdf.

Kristiana, Anita. (2002). Pengaruh Harga Ekspor Tekstil dan Nilai Tukar terhadap Volume Ekspor Tekstil Indonesia ke Jepang tahun 1980-2000. Skripsi Universitas Jember. Jember. $35 \mathrm{hlm}$.

Lipsey, R. G. (1995). Pengantar Makroekonomi Edisi Kesepuluh. Jakarta: Binarupa Kasara.

Mankiw, N.G. (2013). Macroeconomics ( ${ }^{\text {th }}$ ed). Amerika Serikat: Worth Publisher.

Maulana, A., Kartiasih, F. (2017). Analisis Ekspor Kakao Olahan Indonesia ke Sembilan Negara Tujuan Tahun 2000-2014. Jurnal Ekonomi dan Pembangunan Indonesia, 17, 103-117. Doi: https://doi.org/10.21002/jepi.v17i2.664.

Muhammad Firdaus, dkk. (2018). Dampak Pergerakan Nilai Tukar Rupiah terhadap Aktivitas Ekspor dan Impor Nasional. Laporan Akhir Pergerakan Nilai Tukar. EXIM Bank: ID

Pinandhita. (2018). Analisis Potensi Diversifikasi Ekspor Produk Turunan Ban Karet dan Variabel yang Mempengaruhi Ekspor Ban Karet ke 9 Negara Non-Tradisional Tahun 2001-2016. Skripsi Sekolah Tinggi Ilmu Statistik. Jakarta. $120 \mathrm{hlm}$.

Raharjo, Bismo Try. (2013). Analisis Penentu Ekspor Kopi Indonesia. Tesis Universitas Brawijaya. Malang. 12 hlm.

Siope, et al. (2012). Export Diversification and Intra-Industry Trade in Africa. United Nations Economic Commission for Africa.

Suryana, A.T., Fariyanti, A., \& Rifin, A. (2014). Analisis Perdagangan Kakao Indonesia di Pasar Internasional. Jurnal Tanaman Industri dan Penyegar, 1(1), 29-40. Doi: http://dx.doi.org/ 10.21082/jtidp.v1n1.2014.p29-40. 